\title{
AKIŲ HERPETINĖS INFEKCIJOS IR JŲ GYDYMAS
}

\author{
Tautvydas Puslys ${ }^{1}$, Laurynas Kacevičius ${ }^{1}$, Vaida Makarevičiené⿱ ${ }^{2}$ \\ ${ }^{1}$ Lietuvos sveikatos mokslu universitetas, Medicinos akademija, Medicinos fakultetas, \\ ${ }^{2}$ Lietuvos sveikatos mokslu universiteto Kauno ligonine
}

Raktažodžiai: herpes simplex virusas, akys, infekcija, keratitas, blefarokonjunktyvitas, retinitas, acikloviras, gancikloviras.

\section{Santrauka}

Herpetinè akių infekcija yra viena iš dažniausių aklumą sukeliančių infekcinių priežasčiu pasaulyje. Herpes simplex virusas yra dviejų tipų. Jie skiriasi plitimo keliu bei sukeliamų pažaidų lokalizacija. Herpetinė infekcija gali pasireikšti tiek akių vokuose, junginèje, tiek gilesnèse akies struktūrose: ragenoje, gyslainejje, tinklainejje. Priklausomai nuo pasireiškimo lokalizacijos, objektyvios apžiūros duomenys taip pat skiriasi, pavyzdžiui, esant blefarokonjunktyvitui, atsiranda vandeningų išskyrų, stebima voko eritema, kuri opejja ir pasidengia šašu. Esant herpetiniam retinitui, atsiranda akies skausmas, padideja akispūdis, regimos drumstelès, staigus regimojo ploto susiaurejjimas. Negydant galimas apakimas. Gydymo parinkimas priklauso nuo pažeistų struktūrų, kadangi gali būti gydoma tiek vietiškai antivirusiniais medikamentais (lašais, peroraliai), tiek sistemiškai gliukokortikoidais. Literatūros apžvalga atlikta naudojant PubMed duomenų bazę bei Google Scholar informacijos paieškos sistemą. Straipsnių paieškai naudoti raktiniai žodžiai anglų kalba (herpes, herpes eye infection, herpes ocular manifestations, herpes treatment, herpes ophthalmic disease, herpes epidemiology, herpes pathophysiology, herpes prevention).

\section{Ivadas}

Herpes simplex (HSV) - tai dvigrandị linijinį DNR genomą turintis neurotropinis virusas, priklausantis alphaherpesvirinae pošeimiui [1]. Išskiriami du pagrindiniai Herpes simplex virusų tipai - HSV-1 ir HSV-2. Šios etiologijos infekcijos yra vienos dažniausių žmogaus virusinių susirgimų. Herpes simplex virusai randami infekuoto asmens organizmo skysčiuose, todèl aktyvi infekcija perduodama artimo kontakto metu, priešingai HSV-1, HSV -2 infekcijos transmisija dažniausia lytiniu keliu [2].
Pirmojo tipo (HSV-1) virusu daugiausia užsikrečiama vaikysteje, kontaktuojant burnos bei lūpų odai ir gleivinei, naujagimio kraujyje sumažejus iš motinos gautų imunoglobulinų titrui. Suaugusiujų genitalijų srities 1 tipo virusas taip pat gali būti perduotas lytinių santykių metu [1]. PSO duomenimis, 3,7 milijardo žmonių, jaunesnių nei 50 metu (67\%) yra infekuoti HSV-1, iš ju 122-192 mln. pasireiškia lytinių organų HSV-1 infekcija. Manoma, kad apie trečdaliui planetos gyventojų nors kartą gyvenime yra pasireiškusi simptominè HSV-1 infekcija. Skaičiuojama, kad priklausomai nuo regiono, seropozityvumas HSV yra 60-95 proc. suaugusiujų, tačiau pastebima, kad infekuotumas populiacijose yra mažejantis [3,4]. 2016 metų PSO duomenimis, didžiausias paplitimas fiksuojamas Afrikoje (88\%), mažiausias - Amerikoje (45\%) [5]. HSV-2 virusas siejamas su lytinių organų herpetinès infekcijos (pūslelinès) pasireiškimu, nors, retais atvejais, gali sukelti infekciją ir nebūdingose lokalizacijose [2,5]. İprastai HSV-1 infekcijos būna asimptominès, o pasireiškę požymiai nèra kliniškai reikšmingi - infekuotos vietos bèrimai ir opelès, nors, labai retais atvejais, pavyzdžiui, imunosupresinių būklių metu, gali komplikuotis encefalitu, aseptiniu meningitu ar net regos praradimu [6].

Tyrimo tikslas - išsiaiškinti herpetinès infekcijos epidemiologinius ir patofiziologinius veiksnius, herpes virusinès infekcijos pasireiškimą akyse bei apžvelgti gydymo gaires.

\section{Tyrimo medžiaga ir metodai}

Literatūros apžvalga buvo atlikta naudojant PubMed duomenų bazę bei Google Scholar informacijos paieškos sistemą. Straipsniams ieškoti naudoti raktiniai žodžiai anglų kalba (herpes, herpes eye infection, herpes ocular manifestations, herpes treatment, herpes ophthalmic disease, herpes epidemiology, herpes pathophysiology, herpes prevention).

\section{Tyrimo rezultatai}

Infekciju lokalizacija. Oftalmologinis herpetinès infekcijos pasireiškimas gali būti regą stipriai žalojanti būklè - 
viena iš dažniausių aklumą sukeliančių infekcinių priežasčių pasaulyje [2].

HSV gali sukelti uždegimines reakcijas skirtingose akies struktūrose: akių vokuose, junginèje, ragenoje, gyslainèje bei tinklainejje. Žinoma, jog nuo lokalizacijos priklauso tiek gijimo procesas, tiek komplikacijų atsiradimas [7]. Lokalizaciją gali nulemti ir viruso tipas, pavyzdžiui, 1 tipas perduodamas per sąlytị su sergančiuoju (oraliniu keliu) ir po kontakto virusas būna latentinejje būsenoje, trišakio nervo ganglijuose, o ịvykus pakartotinei sensibilizacijai virusu šis reaktyvuojasi ir gali sukelti tiek paviršinio epitelio, tiek stromos keratitus ar endotelitus, o 2 tipas, nors ir perduodamas lytiniu keliu, tačiau taip pat gali pasireikšti akių srityje, kadangi reaktyvavęsi virusai kyla nuo kryžmeninių ganglijų aukštyn ir pasireiškia užpakaliniame akies segmente kaip uveitas ar ūmi tinklainès nekrozè. Herpes simplex viruso 1 tipas pasireiškia dažniausiai, o antrojo tipo raiška akyse labai reta - dažniausiai pasitaiko tik tarp naujagimių, kuriems virusas buvo perduotas gimdymo metu natūraliais takais ar per placentą [8]. Nors pirminė HSV-1 akyse dažniausiai yra vietinè, pasireiškia blefarokonjunktyvitu, uždegiminèmis akių vokų pūslelèmis, o priekinio akies segmento pažaida yra sąlyginai reta infekcijos išraiška, tačiau dažna HSV-1 reaktyvacija šios patologijos tikimybę padidina $[9,10]$, todèl ankstyva herpetinių akies infekcijų diagnostika ir tinkamo gydymo paskyrimas yra esminè priemoné, siekiant išvengti galimų komplikacijų.

Patogenezè. Tipišką HSV patogenezę sudaro ciklas, susidedantis iš pirminès infekcijos epitelio ląstelèse, latentinės fazės neuronuose bei reaktyvacijos. HSV-1 replikacija prasideda infekcijos vietoje, dažniausiai burnos gleivinès ar odos epitelio ląstelèse [11]. Viruso paviršiaus glikoproteinų $\mathrm{gB}$ ar $\mathrm{gC}$ su epitelio ląstelių paviršiaus receptoriais sąveikoje ịvyksta virusinio apvalkalo ir ląstelių plazminès membranos susiliejimas, sąlygojantis viruso genomo patekimą ị ląstelę ir naujų virusinių dalelių sintezę [12]. Tuomet vyksta retrogradinè viruso migracija aksonu ị nervinị mazgą, kuriame virusas neapibrèžtą laiko tarpsni persistuoja iki reaktyvacijos stadijos. HSV-1 išvengia imuninès sistemos poveikio skatindamas glikoproteino CD1d viduląstelinį susitelkimą antigeną pristatančiose ląstelèse, taip slopinant $\mathrm{T}$ ląstelių medijuojamą imuninị atsaką [1].

Išskiriama pirminė ir pasikartojanti akių herpetinè infekcija. Pirminę infekciją dažniausiai sukelia tiesioginis viruso patekimas ant akies paviršiaus, arba ji kyla iš herpesvirusinès infekcijos burnos ir veido srityje, virusui retrogradiškai keliaujant trišakio nervo šaka - akiniu nervu [13]. Imunosupresyviems asmenims pirminę infekciją gali sukelti autoinokuliacija iš aktyvios herpetinès infekcijos židinių kitose organizmo vietose. Gerokai dažniau akių herpetinę infekciją sukelia latentinès stadijos Herpes simplex viruso reaktyvacija [2]. HSV ị organizmą dažniausiai patenka artimo kontakto metu su aktyviomis burnos, lūpų ar lytinių organų gleivinès pažaidomis ar viruso dalelių turinčiomis seilèmis. Dominuojanti infekcijos sritis yra burnos ir veido regionas, kurios yra inervuojamos trišakio nervo šaka - viršutinio žandikaulio nervu. Virusas šia šaka keliauja ị trišakio nervo mazgą, kurio neuronuose būna latentinès būsenos [13]. Tam tikri stimulai, pavyzdžiui, trauma, ultravioletinè spinduliuote, imunosupresija, stresas, hormoniniai pokyčiai (menstruacijos) skatina viruso perejjimą į aktyvią būseną. Reaktyvacijos metu virusas iš trišakio mazgo plinta akiniu nervu ir pasiekia ragenos paviršių, kuriame išplinta. Tokiu būdu viruso reaktyvacija sukelia kliniškai reikšmingą infekciją akyje, nesant prieš tai buvusios odos ar gleivinių pūslelinès [11].

Herpes virusams patekus ant ragenos, aktyvuojami neutrofilai, makrofagai, NK ląstelès ir dendritinès ląstelès, kurių sekretuojami prouždegiminiai mediatoriai slopina viruso dauginimąsi. Pastebèta, kad šie procesai gali sukelti ragenos neovaskuliarizaciją, drumstèjimą bei randèjimą [12]. Identiški procesai vyksta ir virusui patekus i junginę bei akių vokų ląsteles [14]. Viruso replikacija bei organizmo gynybinè imuninè reakcija sukelia akies skausmingumą, aplinkinių audinių patinimą, paraudimą, jautrumą šviesai, ašarojimą bei sutrikusị regejjimą. Negydyti ar neadekvačiai gydyti atvejai sąlygoja ragenos randejjimą, antrinę (bakterinę ar grybelinę) infekciją. Virusui pažeidus regos nervą, vystosi glaukoma $[2,15]$.

Herpes simplex viruso išraiška akyse. Dažniausiai pasitaikanti infekcija aptinkama ragenoje. Priklausomai nuo viruso pobūdžio, pažeidžiami skirtingi ragenos sluoksniai. Žinoma, jog dèl aktyvios herpes simplex viruso replikacijos pažeidžiami paviršiniai epiteliniai sluoksniai, tad šị procesą galime apibūdinti kaip paviršinių epiteliocitų lizę, o stromos pakenkimai atsiranda dèl imunologinių mechanizmų, kovojančių prieš didelę viruso koncentraciją (virusas gali būti ir latentinejje fazèje), kai pažeidžiami gilesnieji sluoksniai. Labai svarbu pastebėti šiuos pažeidimų skirtumus, nes nuo jų priklauso gydymo taktikos parinkimas [16]. Kliniškai epitelinis keratitas pasireiškia skausmu, niežuliu, šviesos baime, neryškiu matymu, ašarojimu ir akių paraudimu, svetimkūnio jausmu akyje. Objektyviai tiriant plyšine lempa, ligos pradžioje matomos pavienès pūslelès ragenos epitelyje, kurios ima trūkinèti ir susilieja, suformuodamos išopejimus, dẻl kurių infekcija plinta ị gilesnius sluoksnius, o pažeidimai geriau matomi, nudažius rageną fluoresceinu [17]. Stromos keratitas, kaip ir kitos akių infekcijos, gali pasireikšti tais pačiais bendriniais akių simptomais. Tiriant plyšine lempa, kartais labai sunku juos pamatyti, kadangi dèl stromos uždegiminès infiltracijos vaizdas būna išbalęs ar nepermatomas. 
Jeigu matomas pilkas-baltas vaizdas, galime įtarti ir nekrotizuojančiąją ligos formą, tačiau tada stebime esančius nekrozès židinius ar išopejjimus. Be išvardintų požymių, galime matyti ragenos edemą ar netgi opos susiformavimą. Ši ligos forma turi vienas prasčiausių baigčių, kadangi ir išgydžius didelius pakitimus akyje sukèlusią infekciją, pažeidimo vietos pradeda randèti dèl fibrozès ir neovaskuliarizacijos [18]. Literatūroje nurodoma, jog dažniausiai pasitaikanti ši ligos forma sukelia aklumą [16-18].

Dar viena infekcijos išraiška yra endotelinis diskinis keratitas - viena retesnių ligos formų. Dažniausiai išsivysto negydant viruso sukeltos infekcijos ar po atliktų chirurginių intervencijų, pavyzdžiui, keratoplastikos. Herpes simplex virusas yra klastingas, kadangi sensibilizavus organizmą, jis lieka visam gyvenimui ir bet kada gali atsinaujinti, nepaisant anksčiau taikyto gydymo bei paskirtų profilaktinių medikamentų dozių. Šiuo atveju pacientai skundžiasi staigiu regèjimo aštrumo sumažèjimu ar išnykimu bei stipria fotofobija. Biomikroskopuojant galima įžvelgti ragenos edemą, seklią priekinę kamerą, gali būti matomi precipitatai ant endotelio, siauras vyzdys, uždegiminiai infiltratai ar sinechijos [19].

Neretai kartu su diskiniu keratitu pasireiškia ir uveitas. Dažniausiai stebimi difuziniai žvaigždiniai precipitatai ir jų pigmentacija ragenoje, spiralinio pobūdžio rainelès atrofija ir pagrindinis simptomas - padidèjęs akispūdis. Jis susijęs su trabekulinio tinklo uždegimu. Pacientai gali skųstis vaizdo susiliejimu, ratilų matymu - padidejjusiu spindesių kiekiu. Negydant šios patologijos, rainelès atrofija išsivysto visuose sluoksniuose. Rainelès sfinkterio tonusas mažeja, raumenys atsipalaiduoja, rainele išsigaubia ir dèl to atsiranda sekli priekinè kamera. Stipraus uždegimo atveju galimas precipitatų kaupimasis priekinès kameros skystyje. Rainelèje aptinkamos kraujosruvos rodo, jog herpetinè infekcija yra labai pažengusi ir agresyvi, kuri vèlyvose stadijose gali sukelti ir antrinę kataraktą [10].

Patognominis visų keratitu požymis - dendritiforminiai epitelio pažeidimai. Panašių radinių galima aptikti ir esant kitų patologijų, pavyzdžiui, citomegalo viruso, adenoviruso, grybelių sukeliamų infekcijų, todèl diferenciacijai ir tiksliai diagnostikai atliekami šie tyrimai: polimerazès grandininè reakcija (PGR), ELISA, IFA [20].

Be aptartų herpetinių infekcijų, akyje dar gali pasireikšti pirminis HSV blefarokonjunktyvitas. Ši patologija būdingesnè vaikams iki 5 metų. Dažniausiai pasireiškia vandeningomis išskyromis ir folikuliniu konjunktyvitu. Herpetinès pūslelès išsidèsčiusios difuziškai ant voko paviršiaus bei krašto, aplink stebima eritema, kuri laipsniškai opejja, pasidengia šašu. Aktyvi viruso replikacija ir skleidimas vyksta dar 10 dienų, tačiau infekcija dažniausiai praeina per 2-3 savaites, nepalikdama rando. Pasikartojančios (latentinès) infekcijos atveju herpetinèms pūslelèms būdingas židininis išsidèstymas palei voko kraštą arba ant voko paviršiaus. Šlapiuojančios opos skleidžia virusą 2-3 dienas. Pasikartojanti infekcija praeina per savaitę. HSV blefarokonjunktyvitui būdingas paausinių limfmazgių padidejimas [14,15,21].

Herpetinis retinitas - grèsmingiausia herpetinès akių infekcijos išraiška. HSV gali sukelti tinklainès nekrozę, kuri dažniausiai yra ūminè (ŪTN) bei progresuojančią išorinę tinklainès nekrozę (PITN). PITN yra sunkesnè virusinio retinito forma, būdingesnè imunodeficitiniams pacientams [22]. Pastebèta, kad HSV sukeltas tinklainès uždegimas būdingesnis jaunesnio amžiaus asmenims. Ūminès tinklainès nekrozès metu stebimi balsvi nekroziški tinklainès plotai, kurių progresavimas priklauso nuo infekcijos eigos, todèl neūmiai besivystanti infekcija dažnai lieka netiksliai diagnozuojama ir atitinkamai negydoma [23]. Remiantis Amerikos uveito draugijos rekomendacijomis, ŪTN diagnozè nustatoma tinklainès periferinèje dalyje stebint bent vieną ar kelis susiliejančius, greitai žiediškai besiplečiančius nekrozinius plotelius, okliuzinị tinklainès vaskulitą ir uždegiminius pakitimus stiklakūnyje bei priekinèje kameroje. Dažnai šiai būklei būdingi simptomai - regos nervo neuropatija, skleritas bei akies skausmingumas. Neretai nustatomas padidejęs akispūdis, tinklainès kraujosruvos bei regos nervo disko edema. Iprastiniai pacientų skundai - akies ar aplinkinių audinių skausmas, diskomfortas judinant akis, paraudimas, fotofobija, regimos drumstelès, suprastejjusi, neryški rega bei regimojo ploto susiaurèjimas. Skirtingai nei ŪTN, PITN atveju nebūdingi stiklakūnio uždegiminiai pakitimai, tinklainès kraujagyslès dažniausiai būna nepažeistos [15,23]. Herpetinio retinito atvejais dažnai (75 proc. atvejų) per pirmuosius tris mènesius nuo simptomų atsiradimo atšoka tinklainè. Retinitas yra pati sunkiausia herpetinès akies infekcijos komplikacija, dažniausiai atspari monoterapijai sisteminiu acikloviru. Baigtis nepalanki, neretai aklumas. Negydant, didžiajai daliai pacientų išnyksta reakcija ị šviesą [23].

Gydymo galimybès. Gydymas priklauso tiek nuo pacientų amžiaus, tiek nuo ligos formos, tačiau žinoma, jog ir negydant herpetinès infekcijos, ši gali praeiti savaime, tačiau sveikimo laikotarpis yra ilgesnis. Netinkamai gydant infekciją, galima pabloginti paciento būklę ir sukelti dar didesnę problemą, tad labai svarbu parinkti tinkamus medikamentus [24].

Iš objektyvios apžiūros galima nuspręsti, bakterinès ar virusinès etiologijos infekcija, todèl skiriamas atitinkamas pirminis - empirinis gydymas. Šiuo herpetinès infekcijos atveju parenkamas antivirusinis gydymas. Dažniausiai naudojami medikamentai: acikloviras, gancikloviras ir valacikloviras. Atsižvelgiant ị viruso aktyvumą, epitelinio keratito metu, kai virusas nuolat replikuojasi, turi būti gydoma akių 
lašais ar peroraliniais antivirusiniais medikamentais, tačiau ne steroidais, nes imunosupresinio poveikio nereikia kai patologiją sukelia ne imunologiniai mechanizmai. Esant stromos pažeidimams, reikalingi steroidiniai medikamentai kartu su peroraliniais antivirusiniais vaistais profilaktikai, tačiau ne akių lašais, nes šiuo atveju yra sisteminis uždegimas ir vietinio poveikio kai aktyvaus viruso nedaug - neužtenka. Šios ligos metu didžiausia viruso koncentracija yra latentinèje fazèje.

Remiantis Amerikos oftalmologijos akademijos duomenimis, epitelini keratitą rekomenduojama gydyti keletu variantų: acikloviru vaikams $12-15 \mathrm{mg} / \mathrm{kg} / \mathrm{d}$, suaugusiems - po 400 mg 3-5 kartus per dieną. Valacikloviru - 500 mg 3 kartus per dieną. Jei skiriame akių lašus, gancikloviro gelis $0,15 \% 5$ kartus per dieną [25].

Keratito su stromos pažeidimais gydymas skiriasi. Jei keratitas be išopėjimų - steroidiniai akių lašai su profilaktine peroralinių antivirusinių medikamentų doze, pavyzdžiui, prednizolono acetatu ar fosfatu $1 \%$ kartu su acikloviru peroraliai 400 mg 2 kartus per dieną ar 500 mg vieną kartą. Jei randama išopejjimų, endotelio pažeidimų, skiriami steroidiniai akių lašai - prednizolono acetatas ar fosfatas $1 \%$ ir antivirusiniu medikamentų gydomosios dozès, kaip ir epitelinio keratito gydymui. Papildomai skiriami drèkinamieji akių lašai, dažniausiai tankesni, didesnès natrio hialuronato koncentracijos, gali būti su karbomero geliu, kad ilgesnį laiką išsaugotų drègnas akis ir nuslopintų vietinius simptomus, tokius kaip skausmas, niežulys bei svetimkūnio jausmas akyse [26].

Herpetinio retinito sukelta tinklainès nekrozè turi būti nedelsiant pradèta gydyti acikloviru $10-13 \mathrm{mg} / \mathrm{kg}$ kas 8 valandas (arba $1500 \mathrm{mg} / \mathrm{m}^{2} / \mathrm{d}$ intraveniškai) 5-10 dienų, toliau 6 savaites -3 mėnesius gydymą tęsiant peroraliai acikloviru $800 \mathrm{mg} 5$ kartus per dieną. Jei matoma regos nervo pažaida, ne anksčiau kaip po 1-2 paru greta reikètų skirti gliukokortikoidu ( $0,5-2 \mathrm{mg} / \mathrm{kg} / \mathrm{d}$ prednizono) peroraliai 6-8 savaites. Stebint nekrozinius plotus makulos srityje, reikalingos intraokulinès injekcijos $(2 \mathrm{mg} / 0,1 \mathrm{ml}$ gancikloviro arba 1,2 - 2,4 $\mathrm{mg} / 0,1 \mathrm{ml}$ foskarneto) [23].

\section{Išvados}

1. Akių herpetinès infekcijos gali pasireiškti ịvairiose akies struktūrose, priklausomai nuo Herpes simplex viruso tipo, kuriuo yra infekuotas žmogus.

2. Infekcijos lokalizacija lemia ligos eigą ir gijimo procesą. Pavyzdžiui, pažeidus gilesnius sluoksnius, kaip ragenos stromą, ši pradeda randèti ir vystosi negrị̌žtami procesai, o tinkamai gydant vokų herpetinę infekciją, pasveikstama be liekamųjų reiškinių.

3. Gydymas taikomas skiriant antivirusinius ir (ar) steroidinius medikamentus terapinėmis arba profilaktinè- mis dozèmis, tačiau tam ịtakos turi infekcijos lokalizacija.

4. Herpetinès infekcijos diferenciacija nuo kitų akių susirgimų labai svarbi, kadangi ši patologija yra viena dažniausių aklumą sukeliančių priežasčių pasaulyje.

\section{Literatūra}

1. Saleh D, Yarrarapu SNS, Sharma S. Herpes Simplex Type 1. StatPearls 2021.

2. Kanukollu VM, Patel BC. Herpes Simplex Ophthalmicus. StatPearls 2021.

3. Farooq AV, Shukla D. Herpes Simplex Epithelial and Stromal Keratitis: An Epidemiologic Update. Surv Ophthalmol 2012;57(5):448-62.

https://doi.org/10.1016/j.survophthal.2012.01.005

4. Looker KJ, Magaret AS, Turner KME, Vickerman P, Gottlieb SL, Newman LM. Global estimates of prevalent and incident herpes simplex virus type 2 infections in 2012. PLoS One 2015;10(1). https://doi.org/10.1371/journal.pone.0114989

5. Looker KJ, Magaret AS, May MT, Turner KME, Vickerman P, Gottlieb SL, et al. Global and Regional Estimates of Prevalent and Incident Herpes Simplex Virus Type 1 Infections in 2012. PLoS One 2015;10(10):e0140765.

https://doi.org/10.1371/journal.pone.0140765

6. Steiner I, Benninger F. Update on Herpes Virus Infections of the Nervous System. Curr Neurol Neurosci Reports 2013;13(12):414.

https://doi.org/10.1007/s11910-013-0414-8

7. Yun H, Lathrop KL, Hendricks RL. A Central Role for Sympathetic Nerves in Herpes Stromal Keratitis in Mice. Invest Ophthalmol Vis Sci 2016;57(4):1749.

https://doi.org/10.1167/iovs.16-19183

8. Dua P, Shinder R, Laskar DB, Lazzaro DR, Rizzuti AE. A case of hypertrophic herpes simplex virus affecting the eyelid and cornea masquerading as IgG4-related disease. Am J Ophthalmol Case Reports 2018;9:68-71.

https://doi.org/10.1016/j.ajoc.2017.12.002

9. Bagga B, Kate A, Joseph J, Dave VP. Herpes simplex infection of the eye: an introduction. Community Eye Heal 2020;33(108):68.

10. Babu K, Konana VK, Ganesh SK, Patnaik G, Chan NSW, Chee S-P, et al. Viral anterior uveitis. Indian J Ophthalmol 2020;68(9): 1764 . https://doi.org/10.4103/ijo.IJO_928_20

11. Zhu L, Zhu H. Ocular herpes: the pathophysiology, management and treatment of herpetic eye diseases. Virol Sin 2014;29(6):327-42.

https://doi.org/10.1007/s12250-014-3539-2

12. Wang L, Wang R, Xu C, Zhou H. Pathogenesis of Herpes Stromal Keratitis: Immune Inflammatory Response Mediated by Inflammatory Regulators. Front Immunol 2020; 11:766.

https://doi.org/10.3389/fimmu.2020.00766 


\section{4}

13. Poccardi N, Rousseau A, Haigh O, Takissian J, Naas T, Deback C, et al. Herpes Simplex Virus 1 Replication, Ocular Disease, and Reactivations from Latency Are Restricted Unilaterally after Inoculation of Virus into the Lip. J Virol 2019;93(24). https://doi.org/10.1128/JVI.01586-19

14. Reddy JC, Rapuano CJ. Current Concepts in the Management of Herpes Simplex Anterior Segment Eye Disease. Curr Ophthalmol Reports 2013;1(4):194-203.

https://doi.org/10.1007/s40135-013-0024-2

15. Kalogeropoulos CD, Bassukas ID, Moschos MM, Tabbara KF. Eye and Periocular Skin Involvement in Herpes Zoster Infection. Med Hypothesis, Discov Innov Ophthalmol 2015;4(4):142.

16. Rowe A, Leger AS, Jeon S, Dhaliwal DK, Knickelbein JE, Hendricks RL. Herpes Keratitis. Prog Retin Eye Res 2013;32C(1):88.

https://doi.org/10.1016/j.preteyeres.2012.08.002

17. Lobo A-M, Agelidis AM, Shukla D. Pathogenesis of herpes simplex keratitis: the host cell response and ocular surface sequelae to infection and inflammation. Ocul Surf 2019;17(1):40. https://doi.org/10.1016/j.jtos.2018.10.002

18. Azher TN, Yin X-T, Tajfirouz D, Huang AJ, Stuart PM. Herpes simplex keratitis: challenges in diagnosis and clinical management. Clin Ophthalmol 2017;11:185.

https://doi.org/10.2147/OPTH.S80475

19. Basak SK, Basak S. Case Report: Recurrence of herpes simplex virus endotheliitis in a Descemet membrane endothelial keratoplasty graft: mimicking fungal interface infection. BMJ Case Rep 2019;12(5).

https://doi.org/10.1136/bcr-2019-229441

20. McGilligan VE, Moore JE, Tallouzi M, Atkinson SD, O'Neill $\mathrm{H}$, Feeney S, et al. A Comparison of the Clinical and Molecular Diagnosis of Herpes Simplex Keratitis. Open J Ophthalmol 2014;4(3):65-74.

https://doi.org/10.4236/ojoph.2014.43011

21. Ryder EC, Benson S. Conjunctivitis. StatPearls 2021.

22. Wu XN, Lightman S, Tomkins-Netzer O. Viral retinitis: diagnosis and management in the era of biologic immunosuppression: A review. Clin Experiment Ophthalmol 2019;47(3):381-95. https://doi.org/10.1111/ceo.13500
23. Bergstrom R, Tripathy K. Acute Retinal Necrosis. StatPearls 2021.

24. Wilhelmus KR. Antiviral treatment and other therapeutic interventions for herpessimplex virus epithelial keratitis. Cochrane database Syst Rev 2015 ;(1):CD002898.

https://doi.org/10.1002/14651858.CD002898.pub5

25. Demystifying the Ocular Herpes Simplex Virus - American Academy of Ophthalmology. https://www.aao.org/eyenet/ article/demystifying-ocular-herpes-simplex-virus\#Table 2

26. Galor A, Moein H-R, Lee C, Rodriguez A, Felix ER, Sarantopoulos KD, et al. Review. Neuropathic Pain and Dry Eye. Ocul Surf 2018;16(1):31.

https://doi.org/10.1016/j.jtos.2017.10.001

\section{HERPES EYE DISEASE AND IT'S TREATMENT}

T. Puslys, L. Kacevičius, V. Makarevičienė

Keywords: herpes simplex virus, eyes, infection, keratitis, blepharoconjunctivitis, retinitis, aciclovir, ganciclovir.

\section{Summary}

Herpetic eyes infection is one of the most common factors to cause blindness by an infection in the world. There are two main types of herpes simplex. The main differences are localisation of lesion and how the infection spread. Herpetic infection can manifest not only in eyelids, conjunctiva, but also in the deeper layers of the eye such as cornea, choroid, retina. Depending on the localisation the objective examinations results can differ. For example, when blepharoconjunctivitis occurs, the main signs are eyelids erythema, watery secretion, which plummet to ulcer. On the other hand, in the occurrence of herpetic retinitis eyesore, elevated eye pressure, turbidity, rapid eyesight fields narrowing develops and if not treated - blindness. Furthermore, depending on the damaged structure, patient can be treated locally by antiviral drugs (drops and oral medication) or systemically by glucocorticoids.

Correspondence to: ptautvydas152@gmail.com

Gauta 2021-08-27 